\title{
Streptomyces spp. Isolated from Potato Scab Lesions Under Nordic Conditions in Finland
}

\author{
Päivi Lindholm, Department of Plant Production, P.O. Box 27, FIN-00014 University of Helsinki; Hanna Korte- \\ maa and Mirkka Kokkola, Department of Plant Biology, P.O. Box 28, FIN-00014 University of Helsinki; Kielo \\ Haahtela, Department of Biosciences, P.O. Box 56, FIN-00014 University of Helsinki; Mirja Salkinoja-Salonen, \\ Department of Applied Chemistry and Microbiology, P.O. Box 56, FIN-00014 University of Helsinki; and Jari P. \\ T. Valkonen, Department of Plant Production, P.O. Box 27, and Institute of Biotechnology, P.O. Box 56, FIN- \\ 00014 University of Helsinki, Finland
}

\begin{abstract}
Lindholm, P., Kortemaa, H., Kokkola, M., Haahtela, K., Salkinoja-Salonen, M., and Valkonen, J. P. T. 1997. Streptomyces spp. isolated from potato scab lesions under Nordic conditions in Finland. Plant Dis. 81:1317-1322.

Actinomycetes isolated from scab lesions of potato tubers in Finland $\left(60^{\circ}-68^{\circ} \mathrm{N}, 21^{\circ}-31^{\circ} \mathrm{E}\right)$ were characterized using physiological tests and production of necrosis on potato minitubers. Seven strains were additionally analyzed for their whole cell fatty acid profiles. The majority of the pathogenic strains were similar to the Streptomyces scabies type strain ATCC 49173 that is characterized by gray to brown colonies, gray spores, spiral sporophores, melanin production, and utilization of the International Streptomyces Project (ISP) sugars. However, two groups of strains (designated as Group 4, 38 strains; and Group 5, nine strains), each containing several pathogenic isolates, differed from S. scabies ATCC 49173 in at least two phenotypic traits. Additionally, a single, highly virulent strain (SSC 122) differed from all other strains for its phenotypic traits. The fatty acid compositions of the three pathogenic strains of Group 4 and the strain SSC 122 differed from S. scabies ATCC 49173 and S. acidiscabies ATCC 49003. In SSC 122 , the ratio of saturated and unsaturated and the iso and anteiso forms of fatty acids were different from all other streptomycetes analyzed. Thus, the strains of Group 4 and 5 and SSC 122 may represent three novel Streptomyces spp. pathogenic on potato. SSC 122 and the pathogenic strains identified to $S$. scabies grew at $\mathrm{pH} 5.0$ but not at $\mathrm{pH} 4.6$, whereas the pathogenic strains of Group 4 and 5 grew at $\mathrm{pH} 4.6$ or 4.4 but not at $\mathrm{pH} 4.2$.
\end{abstract}

Streptomyces scabies Waksman \& Henrici occurs worldwide and causes common scab on potato tubers (13). The type strain of S. scabies (ATCC 49173) (17) is characterized by gray spores born in spiral chains (sporophores), melanin pigment production on tyrosin-containing medium (peptone iron agar), and utilization of all the diagnostic sugars recommended by the International Streptomyces Project (ISP) (32) for identification of Streptomyces spp. S. scabies does not grow at $\mathrm{pH} 4.5$ (17). Subsequently, common scab is less severe in acidic soils and does not usually occur in soils of $\mathrm{pH}<5.2$. Severity of common scab can also be reduced by maintaining high soil moisture with irrigation and by growing resistant cultivars (13).

Corresponding author: J. P. T. Valkonen, Genetic Centre, Box 7025, Swedish University of Agricultural Sciences, S-750 07 Uppsala, Sweden.

E-mail: jari.valkonen@gen.siu.se

Current address of H. Kortemaa: Plant Production Inspection Centre, Seed Testing Department, P.O. Box 111, FIN-32201 Loimaa, Finland.

Accepted for publication 14 August 1997.

Publication no. D-1997-0917-01R

(C) 1997 The American Phytopathological Society
Other Streptomyces species that cause scab on potato tubers also are known $(9,22)$. They usually have been detected in potato scab lesions that have developed under conditions less favorable for the growth of $S$. scabies. All of them are distinguished from $S$. scabies based on flexuous sporophores and lack of melanin production. S. acidiscabies, identified in North America $(7,18)$, causes symptoms similar to those of $S$. scabies but tolerates more acidic soil conditions and grows at $\mathrm{pH}$ 4.5. The type strain of $S$. acidiscabies (ATCC 49003) (18) does not utilize raffinose. $S$. caviscabies $(6,8)$ causes deep-pitted scab under high moisture conditions in Canada. The only ISP sugar utilized by S. caviscabies is raffinose, which clearly distinguishes this species from other Streptomyces spp. pathogenic on potato. Many Streptomyces strains that may represent several as yet unidentified species have been isolated from scab lesions on tubers grown under heavy irrigation in Israel (3). Several unknown Streptomyces spp. cause russet scab and netted scab in potatoes in North America and Europe, respectively (31). In fact, symptoms of russet and netted scab are similar, but the disease is named differently for the two continents because different Streptomyces spp. are probably involved and the optimal conditions for disease development are different. Some (5) but not all (10) Streptomyces strains that cause russet scab resemble $S$. aureofaciens. The Streptomyces strains that cause netted scab under cool temperatures and in acidic and humid soils in Sweden grow under more acidic conditions in vitro than $S$. scabies and are most prevalent in the northern parts of the country (1).

No comprehensive study has examined the diversity among actinomycetes causing scab on potato tubers under Nordic conditions. In Finland $\left(60^{\circ}-70^{\circ} \mathrm{N}, 21^{\circ}-31^{\circ} \mathrm{E}\right)$, over 30 cultivars of potato are grown all over the country under highly variable environmental conditions. Annual precipitation (600-700 mm) exceeds evaporation, which results in leaching and acidification of the field soils and makes frequent liming necessary (25). According to a survey carried out by the Finnish Soil Analysis Service (Viljavuuspalvelu OY) during 1992-1994, the field soils in Finland have low $\mathrm{pH}$ values (5.6-6.0) particularly in the northern parts of the country. Although many growing seasons are characterized by cool temperatures and high humidity, long periods of drought and high mean temperatures may occur in all regions of the country. The soil types vary widely, even within a field (25). It is hypothesized that these Nordic conditions may contribute to the development of pathogenic actinomycetes that express novel combinations of traits adapted to the local conditions.

The objectives of this study were to investigate whether Streptomyces spp. other than S. scabies occur and cause potato scab in Finland and to test whether the pathogenic actinomycetes isolated from potato scab lesions in Finland grow under conditions more acidic than does $S$. scabies.

\section{MATERIALS AND METHODS}

Isolation of actinomycetes. Tubers of 30 potato cultivars with scab symptoms were collected from fields at 21 locations in Finland (Table 1, Fig. 1). Isolation of actinomycetes from the scab lesions was carried out essentially as described by Lawrence (20). Tubers were washed, surface-sterilized with $1.0 \%$ sodium hypochlorite for $1 \mathrm{~min}$, and rinsed with sterile 
water. Scab lesions were excised and ground with a pestle and mortar in sterile water $(1 \mathrm{~g} / 10 \mathrm{ml})$. One $\mathrm{ml}$ of the homogenate was mixed with $9 \mathrm{ml}$ of phenol-water suspension (1:140). Dilutions of the homogenate/water-phenol mixture were spread on yeast malt extract medium
(YME) (32) and incubated at $28^{\circ} \mathrm{C}$. Pure cultures were obtained through three repeated cultures of a single colony on potato-dextrose agar (Difco).

Morphological and physiological characterization. The morphology of the sporophores was examined microscopi-

Table 1. Streptomyces strains examined in this study

\begin{tabular}{|c|c|c|}
\hline Sampling site ${ }^{\mathrm{a}}$ & Potato cultivar & Strain number \\
\hline \multirow[t]{12}{*}{ 1. Apukka } & Amazone & 261 \\
\hline & Aminca & 259,260 \\
\hline & Fambo & 265 \\
\hline & Hankkijan Tanu & $252-254$ \\
\hline & Hankkijan Timo & 256 \\
\hline & Matilda & 251 \\
\hline & Ostara & 263 \\
\hline & Rekord & 264 \\
\hline & Sabina & 255 \\
\hline & Satu & 266 \\
\hline & Timante & 257 \\
\hline & Van Gogh & 250 \\
\hline \multirow[t]{2}{*}{ 2. Helsinki } & Pito & 323 \\
\hline & Rosamunda & 281,282 \\
\hline 3. Kaasmarkku & Matilda & 309,310 \\
\hline 4. Kajaani & Gloria & $338,339,360,361$ \\
\hline 5. Karvia & Bintje & $343-345$ \\
\hline \multirow[t]{2}{*}{ 6. Kokemäki } & Bintje & 314 \\
\hline & Saturna & 312,313 \\
\hline 7. Köyliö & Matilda & 315 \\
\hline 8. Laukaa & unknown & 318 \\
\hline 9. Liminka & Sabina & 347 \\
\hline 10. Loimaa & unknown & 316,317 \\
\hline \multirow{4}{*}{ 11. Lumijoki } & Adora & 333 \\
\hline & Regina & 336 \\
\hline & Ute & 355,356 \\
\hline & unknown & 279,280 \\
\hline \multirow[t]{12}{*}{ 12. Mikkeli } & Adora & 294 \\
\hline & Amazone & 295 \\
\hline & Asterix & 288 \\
\hline & Fambo & 286,287 \\
\hline & Felsina & 289,290 \\
\hline & Hankkijan Timo & 293 \\
\hline & Matilda & 283 \\
\hline & Rocket & 299,300 \\
\hline & Satu & 291 \\
\hline & Sini & 292 \\
\hline & Ukama & $296-298$ \\
\hline & Van Gogh & 285 \\
\hline 13. Padasjoki & unknown & 325,326 \\
\hline 14. Partala, Juva & Matilda & $301-305$ \\
\hline 15. Peipohja & Matilda & 307,308 \\
\hline 16. Ristiina & Matilda & 327 \\
\hline 17. Ruukki & Bintje & 321 \\
\hline \multirow[t]{2}{*}{ 18. Sotkamo } & Matilda & 268,270 \\
\hline & Van Gogh & 267 \\
\hline 19. Säkylä & Saturna & 375 \\
\hline \multirow[t]{17}{*}{ 20. Tyrnävä } & Amazone & 350,351 \\
\hline & Bintje & $331,349,365,379,380$ \\
\hline & Fambo & 342,364 \\
\hline & Hankkijan Timo & $332,352,358,377$ \\
\hline & Hertha & 272 \\
\hline & Kardal & 271 \\
\hline & Kulta & $276-278$ \\
\hline & Matilda & $359,370,374$ \\
\hline & Olympia & 357,376 \\
\hline & Pito & 372,373 \\
\hline & Puikula & $273-275,371$ \\
\hline & Rekord & $337,366-368$ \\
\hline & Rosamunda & 363 \\
\hline & Sabina & $329,330,341,346,353$ \\
\hline & Saturna & 381 \\
\hline & Siikli (Sieglinde) & 334,362 \\
\hline & Van Gogh & 348 \\
\hline 21. Ylistaro & Bintje & 319,320 \\
\hline
\end{tabular}

${ }^{a}$ Numbers are identical to those in Figure 1.

cally at $\times 400$ magnification, and the color of spores and colonies were observed on YME after 14 days of incubation at $28^{\circ} \mathrm{C}$ $(12,32)$. Production of melanin was observed on peptone yeast extract iron medium (PYI; Difco) after 4 days of incubation at $28^{\circ} \mathrm{C}$ (32). The ability to utilize the International Streptomyces Project (ISP) sugars was tested on the standard basal medium (32). Pathogenic actinomycete strains were tested for their lower $\mathrm{pH}$ limit of growth on YME adjusted to $\mathrm{pH} 4.0-5.2$ at 0.2 unit intervals; growth of colonies was observed after 14 days of incubation at $28^{\circ} \mathrm{C}$. Tests were carried out twice.

Fatty acid analysis. Analyses for the whole cell fatty acids were carried out in parallel in two laboratories, namely at the Department of Applied Chemistry and Microbiology, University of Helsinki (UH), and the Deutsche Sammlung von Mikro-organismen und Zellkulturen (DSMZ), Braunschweig, Germany. Three pathogenic strains of Group 1a (strains 267, 289, and 302) and Group 4 (strains 287, 298, and 300), strain SSC 122 (27) (provided by J. Kankila, Department of Plant Biology, University of Helsinki), and type strains S. scabies ATCC 49173 and $S$. acidiscabies ATCC 49003 (provided by R. Loria, Department of Plant Pathology, Cornell University, NY) were analyzed in both laboratories. Additionally, S. scabies DSM $41568^{\mathrm{T}}$ and S. acidiscabies DSM $41668^{\mathrm{T}}$ were included in the analyses at DSMZ. Culture of the actinomycetes in trypticase soy broth (TSB) at $28^{\circ} \mathrm{C}$, sample preparation, and the analysis of the whole

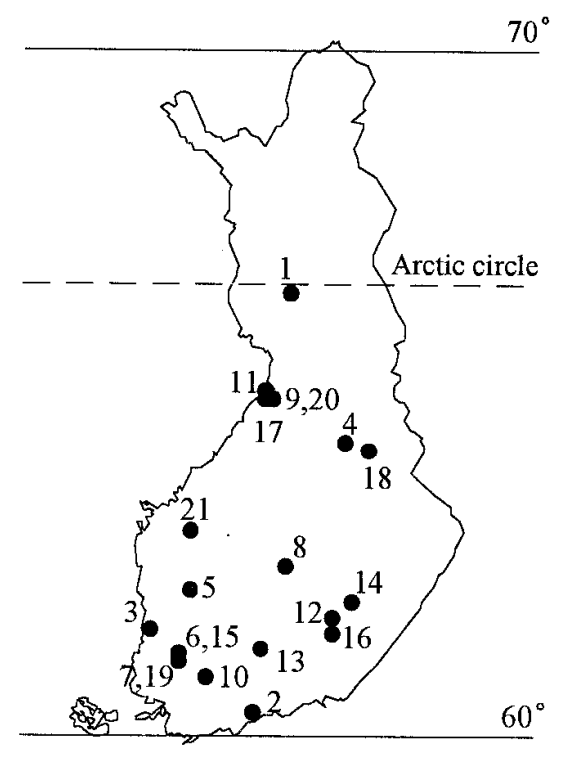

Fig. 1. Sampling sites in Finland of the actinomycete strains examined in this study. $1=$ Apukka, 2 = Helsinki, $3=$ Kaasmarkku, $4=$ Kajaani, $5=$ Karvia, $6=$ Kokemäki, $7=$ Köyliö, $8=$ Laukaa, $9=$ Liminka, $10=$ Loimaa, $11=$ Lumijoki, 12 = Mikkeli, 13 = Padasjoki, 14 = Partala, Juva, 15 = Peipohja, $16=$ Ristiina, $17=$ Ruukki, 18 = Sotkamo, $19=$ Säkylä, $20=$ Tyrnävä, 21 = Ylistaro. 
cell fatty acids by the MIDI Microbial Identification System MIS (Microbial ID, Newark, DE) were carried out according to the manufacturer's instructions as previously described $(14,15,24,28)$. The rate of growth varied among strains, but harvesting of cell masses was carried out at the mid-log phase $(12,30)$, which was reached after 2-4 days using the DSMZ method (15). Cluster analysis was carried out using the unweighted pair group method Algorithm (UPGMA) as previously described (15). In both laboratories, fatty acid analyses of the strains were carried out twice.

Pathogenicity tests. Pathogenicity was tested according to the procedure provided by R. Loria and B. A. Fry (Cornell Univer- sity, Ithaca, NY). Healthy minitubers of potato cv. Matilda (susceptible to common scab) $(27,36)$ were produced from leaf-bud cuttings in washed sand in the greenhouse as described elsewhere (19). Tubers had a white, thin skin similar to microtubers produced in vitro and were formed at the apex of short stolons. They were harvested when they were $1-1.5 \mathrm{~cm}$ in diameter (Fig. 2). Actinomycetes were grown in oat meal broth $(\mathrm{OMB})(15 \mathrm{ml})$ for 4 days at $28^{\circ} \mathrm{C}$ under shaking (150 rpm). Three minitubers were soaked in the OMB and incubated on a moist filter paper in a petri dish in the dark for 4 days. Minitubers soaked into non-inoculated OMB were used as healthy controls, whereas minitubers inoculated

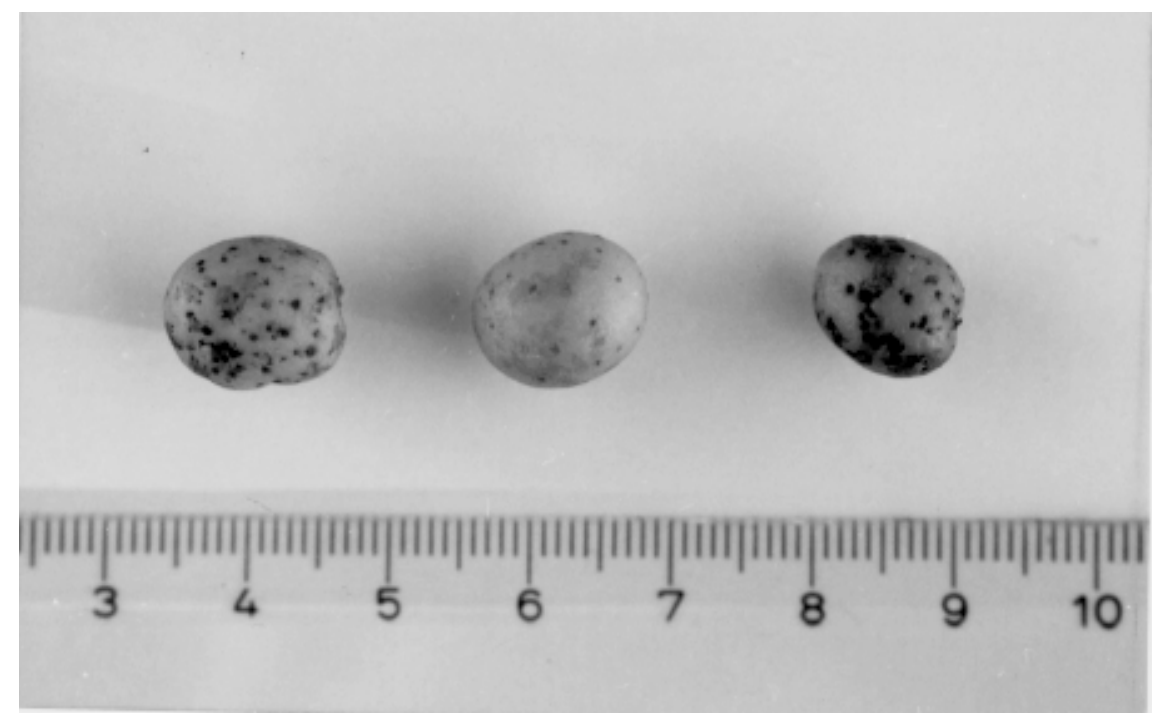

Fig. 2. Necrosis induced on minitubers of potato cv. Matilda 3 days after inoculation in vitro with strain SSC 122 (left tuber) and strain 376 (S. scabies, Group 1a) (right tuber). The tuber in the center was treated with noninoculated oatmeal broth. The scale is in centimeters.

with S. scabies ATCC 49173, S. scabies SSC101, or strain SSC122 were used as positive controls in all experiments. Many strains were re-tested for up to three times.

\section{RESULTS}

A total of 118 actinomycete strains were obtained from scab lesions on tubers of 30 potato cultivars (Table 1). Strains were collected from 21 geographic locations, including one to six strains from most geographic regions. However, the largest numbers of strains came from Apukka, the northern-most sampling site at the Arctic circle (15 strains); Tyrnävä, the legally protected seed potato production zone of the Seed Potato Center (44 strains); and from Mikkeli (17 strains) (Table 1, Fig. 1).

Phenotypic characterization and pathogenicity. Strains were grouped based on color of colonies and spores, sporophore morphology, melanin production, and utilization of the ISP sugars (Table 2). Group 1a consisted of 37 strains that had gray spores, spiral sporophores, produced melanin, utilized all the ISP sugars, and were identical to $S$. scabies ATCC 49173. Five strains differed from Group 1a in that they were negative for the utilization of one, or more, of the three sugars Dmannitol, sucrose, or D-xylose and were placed in Group 1b. In Group 1a, 34 of the 37 strains were pathogenic on potato, whereas in Group 1b only one strain was pathogenic. Group 2 contained five strains that differed from Group 1a by not producing melanin, and they were nonpathogenic. Strain SSC 122 (27) was similar to the strains of Group 2 based on the phenotypic traits shown in Table 2, but it was pathogenic on potato. Group 3 consisted of three strains that differed from Group 1a by having flexuous sporophores. Two of them (strains 321 and 380) utilized all ISP sugars, and the strain 380 was pathogenic, whereas strain 259 did not utilize sucrose and meso-inositol and was nonpathogenic (Tables 2 and 3).

Table 2. Phenotypic comparison and grouping of the Streptomyces spp. isolated from potato tubers in Finland ${ }^{\mathrm{a}}$

\begin{tabular}{|c|c|c|c|c|c|c|c|}
\hline Trait & Group 1a & Group 1b & Group 2 & Group 3 & Group 4 & Group 5 & Group 6 \\
\hline Colony color on YME medium & Gray to brown & Gray to brown & Gray to brown & Gray to brown & Tan & Yellow & $\mathrm{V}$ \\
\hline Spore color & Gray & Gray & Gray & Gray & Gray & Gray & $\mathrm{V}$ \\
\hline Sporophore morphology & Spiral & Spiral & Spiral & Flexuous & Flexuous & Flexuous & $\mathrm{V}$ \\
\hline Melanin production & + & + & - & + & - & - & V \\
\hline \multicolumn{8}{|l|}{ Utilization of ISP sugars } \\
\hline $\mathrm{L}$-arabinose & + & + & + & + & + & $\mathrm{V}$ & $\mathrm{V}$ \\
\hline D-fructose & + & + & + & + & + & + & + \\
\hline D-glucose & + & + & + & + & + & + & + \\
\hline D-mannitol & + & $\mathrm{V}$ & + & + & + & + & $\mathrm{V}$ \\
\hline raffinose & + & + & + & + & + & $\mathrm{V}$ & $\mathrm{V}$ \\
\hline rhamnose & + & + & + & + & + & + & + \\
\hline sucrose & + & V & + & $\mathrm{V}$ & + & $\mathrm{V}$ & $\mathrm{V}$ \\
\hline D-xylose & + & V & + & + & + & V & V \\
\hline meso-inositol & + & + & + & $\mathrm{V}$ & + & $\mathrm{V}$ & $\mathrm{V}$ \\
\hline Growth at $\mathrm{pH}=4.5^{\mathrm{b}}$ & - & - & nt & - & + & + & nt \\
\hline Pathogenicity on potato & $34 / 37^{\mathrm{c}}$ & $1 / 5$ & $0 / 5$ & $1 / 3$ & $6 / 38$ & $2 / 9$ & $0 / 21$ \\
\hline
\end{tabular}

a Variable traits within the groups are indicated by V.

b Tested only with the pathogenic strains.

${ }^{c}$ Number of pathogenic strains out of the total number of strains. 
Group 4 consisted of 38 strains obtained from 11 geographic locations, including the northern-most (Apukka) and southernmost (Helsinki) sampling sites (Tables 1, 2, and 3 and Fig. 1). They had tan colonies, gray spores, flexuous sporophores, and did not produce melanin, but they utilized all the ISP sugars. Six strains were pathogenic on potato. Group 5 contained nine strains that were similar to Group 4, except that their colonies were yellow and they did not utilize all the ISP sugars. Two strains of Group 5 were pathogenic.

Twenty-one non-pathogenic strains could not be placed to any of the five groups described above, and they were placed in Group 6 (Tables 2 and 3).

Growth under acidic conditions. The pathogenic strains of Groups 1-3 grew at pH 5.0 or 4.8 , but strain 341 (Group 1a) grew weakly at pH 4.6 (Table 2). SSC 122 and S. scabies ATCC 49173 grew at $\mathrm{pH} 4.8$ but not at $\mathrm{pH} 4.6$.

All pathogenic strains of Groups 4 and 5 (Table 2) tolerated more acidic conditions than did Group 1 and 3 strains. Strains 257, 287 (Group 4), and 317 (Group 5) grew at $\mathrm{pH} 4.6$ but not at $\mathrm{pH}$ 4.4. Strains 294, 298, 300, 334 (Group 4), and 316 (Group 5) grew at $\mathrm{pH} 4.4$ but not at $\mathrm{pH} 4.2$. S. acidiscabies ATCC 49003 grew at pH 4.2 but not at $\mathrm{pH} 4.0$.

Fatty acid composition. The fatty acid composition of SSC 122 clearly differed from the other Streptomyces strains analyzed (Table 4). SSC 122 contained 2hydroxypentadecanoic acid, which was not detected in other strains and did not contain 9-methyl hexadecanoic acid, which was detected in all other strains analyzed. The ratio of anteiso:iso forms of pentadecanoic acid was 5.9 in SSC 122, 2.9 in $S$.

Table 3. Capacity of the actinomycetes strains of different groups, defined based on phenotypic criteria, to induce necrosis on minitubers of potato cv. Matilda in the in vitro tests

\begin{tabular}{lll}
\hline $\begin{array}{l}\text { Group } \\
\text { number }\end{array}$ & Necrosis induced & Necrosis not induced \\
\hline $1 \mathrm{a}$ & $267,270,274,281,282,288,289,291$, & $271,272,333$ \\
& $301-303,205,315,329,330,336,337$, & \\
\multicolumn{3}{l}{$339,341,345,347,348,355,356,362}$, \\
$1 \mathrm{~b}$ & $370-377,379$ & $273,313,346,360$ \\
2 & 364 & $299,338,351,357,363$ \\
3 & - & 259,321 \\
4 & 380 & $250-253,255,256,261,264,266,268,283$, \\
& $257,287,294,298,300,334$ & $285,286,292,293,295,297,304,309,314$, \\
& & $323,325,331,332,342-344,350,352,359$, \\
5 & 316,317 & 365,368 \\
6 & - & $254,275-278,310,320$ \\
& & $312,318,319,326,327,349,353,358,361$, \\
& & $366,367,381$ \\
\hline
\end{tabular}

acidiscabies ATCC 49003, 1.1-1.7 in Group 1a strains, $0.9-1.0$ in Group 4 strains, and 0.8 in S. scabies ATCC 49173. Similarly, the ratio of anteiso:iso forms of heptadecanoic acid was 6.3 in SSC 122 , 3.4 in S. acidiscabies ATCC 49003, 2.43.6 in Group 1a strains, $1.4-1.6$ in Group 4 strains, and 1.4 in S. scabies ATCC 40173. The ratio of the unsaturated cis-9hexadecenoic acid and the saturated hexadecanoic acid was lower in SSC $122(0.3)$ than in S. acidiscabies ATCC 49003 (0.7), Group 4 (0.6-0.8) and Group 1a (1.3-1.7) strains, and in S. scabies ATCC 49173 (1.2). The strains of Group 4 and S. acidiscabies ATCC 49003 differed from the other strains in that they contained cyclopropaneheptadecanoic acid. Clustering of the strains based on the fatty acid profiles (not shown) using the generally accepted Euclidian distance of less than 10.0 as a taxonomic standard for distinguishing species $(26,30)$ showed that $S$. acidiscabies and SSC 122 were both placed in a cluster of their own. The three strains of Group 4 had a rather similar fatty acid composition and formed one cluster. S. scabies ATCC 49173 was placed to a cluster different from the strains of Group 1a.

\section{DISCUSSION}

S. scabies (type strain ATCC 49173) is characterized by spiral sporophores and gray spores, production of melanin pigment on peptone-iron agar, utilization of all ISP sugars, and pathogenicity on potato (17). These traits are simple to analyze, have historically been used for the detection of S. scabies and more recently for recognizing novel Streptomyces species which are pathogenic on potato and distinct

Table 4. Proportions of whole cell fatty acids (\%) in selected Streptomyces strains pathogenic on potato at the mid-log phase of growth (2-4 days)

\begin{tabular}{|c|c|c|c|c|c|c|c|c|c|c|}
\hline \multirow[b]{2}{*}{ MIDI acronym } & \multirow[b]{2}{*}{ Fatty acid } & \multicolumn{4}{|c|}{ Strains of S.scabies } & \multicolumn{3}{|c|}{ Strains of Group 4} & \multirow[b]{2}{*}{ SSC 122} & \multirow{2}{*}{$\begin{array}{l}\text { S. acid- } \\
\text { iscabies }^{\mathrm{a}}\end{array}$} \\
\hline & & 49173 & 267 & 289 & 302 & 287 & 298 & 300 & & \\
\hline $14: 0$ iso & iso tetradecanoic & $2.0(0.7)^{\mathrm{b}}$ & $2.9(0.1)$ & $7.3(4.3)$ & $3.4(1.2)$ & $6.7(0.5)$ & $7.9(0.4)$ & $9.5(0.6)$ & $15.0(2.5)$ & $5.2(0.9)$ \\
\hline $15: 0$ iso & iso pentadecanoic & $14.9(0.9)$ & $8.4(0.3)$ & $9.8(1.0)$ & $7.2(1.8)$ & $12.5(1.2)$ & $11.4(0.6)$ & $12.3(0.4)$ & $3.5(0.4)$ & $7.1(0.9)$ \\
\hline 15:0 anteiso & anteiso pentadecanoic & $11.7(0.4)$ & $12.4(1.7)$ & $10.6(1.6)$ & $12.0(3.8)$ & $13.2(1.6)$ & $10.7(0.5)$ & $11.9(0.9)$ & $20.7(0.1)$ & $20.9(0.7)$ \\
\hline $15: 0$ anteiso $2 \mathrm{OH}$ & $\begin{array}{l}\text { anteiso 2-hydroxy- } \\
\text { pentadecanoic }\end{array}$ & $n d^{c}$ & nd & nd & nd & nd & nd & nd & $3.0(0.1)$ & nd \\
\hline $15: 0$ & pentadecanoic & $5.7(2.1)$ & $4.5(0.6)$ & $3.7(0.7)$ & $3.2(0.0)$ & $3.6(0.6)$ & $2.9(0.0)$ & $4.4(0.1)$ & $9.8(0.9)$ & $2.7(0.5)$ \\
\hline $16: 1$ iso $\mathrm{H}^{\mathrm{d}}$ & iso hexadecenoic & $2.2(0.2)$ & $5.4(1.1)$ & $10.3(2.6)$ & $6.9(3.4)$ & $4.7(1.3)$ & $7.8(0.6)$ & $4.2(1.1)$ & $3.6(0.1)$ & $1.8(0.2)$ \\
\hline $16: 1$ cis 9 & cis-9-hexadecenoic & $13.2(2.1)$ & $8.9(1.6)$ & $8.7(1.6)$ & $9.6(3.7)$ & $6.4(0.8)$ & $6.1(1.4)$ & $5.6(1.5)$ & $1.4(0.1)$ & $11.6(0.3)$ \\
\hline $16: 0$ & hexadecanoic & $10.6(0.4)$ & $6.0(1.2)$ & $5.2(3.0)$ & $7.3(3.1)$ & $9.4(1.9)$ & $7.2(2.3)$ & $9.1(1.5)$ & $5.5(0.5)$ & $16.2(0.3)$ \\
\hline $16: 0$ iso & iso hexadecanoic & $12.4(1.2)$ & $24.4(4.1)$ & $26.4(3.4)$ & $27.8(9.9)$ & $21.8(2.1)$ & $25.3(2.1)$ & $23.9(2.7)$ & $22.0(2.4)$ & $17.6(0.9)$ \\
\hline $16: 0$ methyl $^{\mathrm{d}}$ & methyl hexadecanoic & $7.5(0.9)$ & $5.5(0.2)$ & $4.9(0.5)$ & $4.6(0.8)$ & $4.8(0.9)$ & $5.0(0.5)$ & $3.4(0.3)$ & nd & $1.7(0.1)$ \\
\hline $17: 1$ anteiso $C^{d}$ & anteiso heptadecenoic & $2.3(0.4)$ & $5.1(0.3)$ & $3.7(0.5)$ & $4.9(1.3)$ & $2.4(0.2)$ & $2.3(0.1)$ & $1.7(0.1)$ & $1.4(0.4)$ & $2.0(0.0)$ \\
\hline $17: 0$ iso & iso heptadecanoic & $4.6(0.7)$ & $2.4(0.2)$ & $1.6(0.8)$ & $2.0(0.4)$ & $3.8(0.1)$ & $3.6(0.1)$ & $3.6(0.1)$ & $1.0(0.2)$ & $2.1(0.5)$ \\
\hline 17:0 anteiso & anteiso heptadecanoic & $6.6(0.4)$ & $7.3(0.7)$ & $3.9(1.7)$ & $7.2(2.0)$ & $6.1(0.4)$ & $5.2(0.3)$ & $5.2(0.1)$ & $6.3(0.4)$ & $7.2(1.2)$ \\
\hline $17: 1$ cis 9 & cis-9-heptadecenoic & $2.5(0.2)$ & $3.1(0.1)$ & $1.6(0.2)$ & $1.8(0.2)$ & $1.6(0.2)$ & $1.5(0.1)$ & $1.5(0.3)$ & $1.0(0.2)$ & $0.5(0.2)$ \\
\hline 17:0 cyclo & $\begin{array}{l}\text { cyclopropanehepta- } \\
\text { decanoic }\end{array}$ & nd & nd & nd & nd & $0.9(0.0)$ & $1.0(0.1)$ & $1.1(0.0)$ & nd & $2.4(0.4)$ \\
\hline $17: 0$ & heptadecanoic & $1.2(0.3)$ & $1.4(0.2)$ & $0.3(0.1)$ & $0.8(0.0)$ & $0.8(0.2)$ & $0.7(0.0)$ & $1.0(0.0)$ & $2.1(0.2)$ & nd \\
\hline Other ${ }^{\mathrm{e}}$ & & 2.6 & 2.3 & 0.0 & 1.3 & 1.3 & 1.3 & 1.6 & 3.7 & 1.0 \\
\hline
\end{tabular}

a ATCC 49003.

${ }^{\mathrm{b}}$ Mean of two whole cell fatty acid extractions at DSMZ. Standard deviation is indicated in parenthesis.

${ }^{\mathrm{c}}$ Not detected.

${ }^{d}$ Position of the double bond and methyl group is uncertain.

e Total proportion of fatty acids, of which each accounted for less than $1.0 \%$. 
from S. scabies $(1,6,7,8,10,18,31)$. Also color of colonies and production of diffusible pigments are criteria for species identification $(8,32)$. In this study, the initial characterizations recommended above were carried out and augmented with the analysis of whole cell fatty acids of seven strains.

Grouping of the actinomycetes based on the phenotypic traits (Table 2) showed that the majority of strains pathogenic on potato were similar to $S$. scabies ATCC 49173 and belonged to Group 1a. However, the fatty acid profiles of the three strains 267, 289, and 302 of Group 1a analyzed at three days of growth contained lower and higher relative amounts of iso pentadecanoid acid and iso hexadecanoid acid, respectively, than did $S$. scabies ATCC 49173 (Table 4). The fatty acid profile of $S$. scabies ATCC 49173 analyzed at 3 days of growth by Ndwora et al. (26) is similar to the profiles of the three strains of Group 1a in our study, and the difference in the fatty acid profiles of $S$. scabies ATCC 49173 obtained in this study and the previous study is probably due to the different culture time (34). Groups $1 b, 2$, and 3 (Table 2) contained the strains that closely resembled $S$. scabies but differed from it in the utilization of the ISP sugars (Group 1b), melanin production (Group 2) or sporophore morphology (Group 3).

In the previous studies, actinomycetes, which deviated from $S$. scabies for any one of these three traits have been included in S. scabies. Goyer et al. (8) described strains of $S$. scabies that do not utilize all ISP sugars. Non melanin-producing strains of $S$. scabies have been described and they are not pathogenic on potato $(2,4,17)$, as also shown in this study (Group 2; Table 2 ). Whether or not Group 3 of this study represented $S$. scabies is unclear, because spiral sporophores are considered as the trait of $S$. scabies, which distinguishes it from all other Streptomycetes spp. pathogenic on potato $(7,17,18,22)$. However, some authors consider strains with flexuous sporophores to be $S$. scabies, provided that other traits are identical to $S$. scabies $(4,9)$.

Several strains that were pathogenic on potato differed from $S$. scabies ATCC 49173 and the strains of Group 1a in at least two phenotypic traits examined and, thus, probably represented other, as yet unidentified, Streptomyces species. On the other hand, many isolated strains were nonpathogenic, which is consistent with the previous studies $(7,23)$. Group 4 contained six pathogenic strains (Tables 2 and 3). Flexuous sporophores, lack of melanin production, and growth at lower $\mathrm{pH}$ distinguished this homogenous group of strains from $S$. scabies. Also, the fatty acid profiles suggested that Group 4 was distinct from S. scabies. Group 5 differed from Group 4 in having yellow colonies and not utilizing all of the ISP sugars. Comparison of Group 5 to the four Streptomyces spp. identified as potato pathogens in Canada (Table 2) showed that it resembled S. aureofaciens, which causes russet scab $(7,8)$, i.e., the type of symptoms named netted scab in Europe (31). Scab symptoms on the tubers, from which the two pathogenic strains of Group 5 were obtained, were not different from the symptoms in other tubers, but it should be noted that the early stages of netted scab symptoms are not easily distinguishable from common scab as illustrated in Scholte and Labruyère (31).

The in vitro test carried out in this study is used for rapid demonstration of pathogenicity of Streptomycetes strains indicated by necrosis that develops in the skin of the inoculated minitubers $(16,21)$, but it does not reveal the true type of scab symptoms that develop on mature tubers. It remains to be shown whether Group 5 causes netted scab in mature tubers. Further physiological, molecular, and pathogenicity tests are required for the more comprehensive description of the species represented by Groups 4 and 5.

The number of strains was almost the same in Groups 4 and 1a (Table 2), but the strains of Group 4 were geographically more widely distributed (Table 3, Fig. 1). Many strains of Group 4 were isolated from Apukka (10 strains of the total of 15 strains), Tyrnävä (9/44), and Mikkeli (11/17) (Table 3; Fig. 1), whereas no strains of Groups 1a, 1b, or 2 were found among the strains from Apukka. However, Group 1a was the largest from Tyrnävä (Table 3) located $250 \mathrm{~km}$ south from Apukka (Fig. 1). It is hypothesized that the different agroclimate and soil conditions in Tyrnävä and Apukka (25) may contribute differently to the abundance of strains of Group 1a and 4 in these regions.

Strain SSC 122 was originally described by Oravuo (27) and is highly virulent on potato. SSC 122 differed from S. scabies in that it did not produce melanin. This observation suggested that SSC 122 did not belong to $S$. scabies because, according to Lambert and Loria (17), melanin production is consistently associated with pathogenicity in $S$. scabies. Additionally, the fatty acid analysis showed that the ratio of anteiso to iso forms of pentadecanoic and heptadecanoic acids in SSC 122 was approximately fivefold bigger, whereas the ratio between the unsaturated cis-9hexadecenoic acid and the saturated hexadecanoic acid was only one-quarter to onehalf of that in S. scabies ATCC 49173 and the strains of Group 1a and 4. In this respect, SSC 122 was more similar to $S$. acidiscabies ATCC 49003 analyzed in this study and the $S$. acidiscabies strains RL 104 and RL 182 analyzed by others (26), but the overall fatty acid profiles of the strain SSC122 and S. acidiscabies were clearly different (Table 4).

It is known that bacteria respond to a decrease of temperature by increasing acyl chain unsaturation or branching in order to maintain membrane fluidity $(29,33)$. In unsaturation, changes are typically observed as an increase of the ratio of cis-9hexadecenoic acid to hexadecanoic acid. Changes in branching are usually observed as an increase of the ratio of anteiso to iso forms in acyl chains with an odd number of carbon atoms, because anteiso forms are more efficient in maintaining membrane fluidity. Based on the results of this study it is hypothesized that in SSC 122, membrane fluidity is primarily maintained through the high proportion of anteiso forms of pentadecanoic and heptadecanoic acids at $28^{\circ} \mathrm{C}$ because the proportion of the cis-9-hexadecenoic acid was very low. Consequently, the strain SSC 122 may have more capacity than the other pathogenic strains examined in this study to adapt to cold by increasing the proportion of the cis-9-hexadecenoic acid. Adaptation to cool growth conditions would be particularly beneficial to a soil-borne pathogen under Nordic conditions, and, therefore, the hypotheses presented above need to be examined in more detail. In conclusion, the data suggested that the strain SSC 122 may represent a previously undescribed potato scab-inducing Streptomyces species.

This study shows that the unknown, pathogenic Streptomyces strains of Groups 4 and 5 were adapted to slightly more acidic conditions than $S$. scabies. Growth under $\mathrm{pH} 4.5$ has previously been described only for $S$. acidiscabies (18), which was not identified among the 118 actinomycete strains examined in this study. The data of this study also showed that diversity among the actinomycetes which induce scab symptoms on potato in Finland is much wider than previously known (11), as has been observed in other countries $(2,7,8,9,22,23,31,35)$. Therefore, control of scab disease in potato will remain complicated until the ecology and control of the locally prevalent scab-inducing species is understood.

\section{ACKNOWLEDGMENTS}

We thank several colleagues for their help in collecting tubers for analysis; Tuula Laine, Seija Elo, and Riitta Boeck for technical assistance; R. M. Kroppenstedt for helpful suggestions and the fatty analysis services; and Rosemary Loria and Barbara Fry, Cornell University, NY, for their advice. This study was financially supported by the University of Helsinki and the Academy of Finland.

\section{LITERATURE CITED}

1. Bång, H. 1979. Studies on potato russet scab. I. A characterization of different strains from northern Sweden. Acta Agric. Scan. 29:145150.

2. De Klerk, A., McLeod, A., Faurie, R., Swart, W. J., and Denner, F. D. N. 1996. Identification and toxin production of Streptomyces isolates responsible for common scab in the Northern Cape province of South Africa Pages 257-258 in: Proc. 13th Trienn. Conf. EAPR, Veldhoven, The Netherlands.

3. Doering-Saad, C., Kämpfer, S., Manulis, G., 
Kritzman, J., Schneider, J., ZakrzewskaCzerwinska, H., Schrempf, H., and Barash, I. 1992. Diversity among Streptomyces strains causing potato scab. Appl. Environ. Microbiol. 58:3932-3940.

4. Elesawy, A. A., and Szabó, I. M. 1979. Isolation and characterization of Streptomyces scabies strains from scab lesions of potato tubers. Designation of the neotype strain of Streptomyces scabies. Acta Microbiol. Acad. Sci. Hung. 26:311-320.

5. Faucher, E., Otrysko, B., Paradis, E. Hodge, N. C., Stall, R. E., and Beaulieu, C. 1993. Characterization of streptomycetes causing russet scab in Quebéc. Plant Dis. 77:12171220.

6. Faucher, E., Paradis, E., Goyer, C., Hodge, N. C., Hogue, R., Stall, R. E., and Beaulieu, C. 1995. Characterization of streptomycetes causing deep-pitted scab of potato in Quebéc, Canada. Int. J. Syst. Bacteriol. 45:222-225.

7. Faucher, E., Savard, T., and Beaulieu, C. 1992. Characterization of actinomycetes from common scab lesions on potato tubers. Can. J. Plant Pathol. 14:197-202.

8. Goyer, C., Faucher, E., and Beauliau, C. 1996. Streptomyces caviscabies sp. nov., from deeppitted lesions in potatoes in Quebéc, Canada. Int. J. Syst. Bacteriol. 46:635-639.

9. Goyer, C., Otrysko, B., and Beaulieu, C. 1996. Taxonomic studies on streptomycetes causing potato common scab: A review. Can. J. Plant Pathol. 18:107-201.

10. Harrison, M. D. 1962. Potato russet scab, its cause and factors affecting its development. Am. Potato J. 39:368-387.

11. Heinämies, H., and Seppänen, E. 1971. Morphological, physiological and pathogenic properties of potato scab organism in Finland. Ann. Agric. Fenn. 10:174-180.

12. Holt, J. G., Krieg, N. R., Sneath, P. H. A., Staley, J. T., and Williams, S. T. 1994. Bergey's Manual of Determinitive Bacteriology, 9th ed. Williams and Wilkins, Baltimore, MD.

13. Hooker, W. J. 1981. Common scab. Pages 3334 in: Compendium of Potato Diseases. American Phytopathological Society, St. Paul, $\mathrm{MN}$.
14. Kämpfer, P., and Kroppenstedt, R. M. 1991. Probabilistic identification of streptomycetes using miniaturized physiological tests. J. Gen. Microbiol. 137:1893-1902.

15. Kämpfer, P., and Kroppenstedt, R. M. 1996. Numerical analysis of fatty acid patterns of coryneform bacteria and related taxa. Can. J. Microbiol. 42:989-1005.

16. King, R. R., Lawrence, C. H., and Clark, M. C. 1991. Correlation of phytotoxin production with pathogenicity of Streptomyces scabies isolates from scab infected potato tubers.Am. Potato J. 68:675-680.

17. Lambert, D. H., and Loria, R. 1989. Streptomyces scabies sp. nov., nom. rev. Int. J. Syst. Bacteriol. 39:387-392.

18. Lambert, D. H., and Loria, R. 1989. Streptomyces acidiscabies sp. nov. Int. J. Syst. Bacteriol. 39:393-396.

19. Lauer, F. I. 1977. Tubers from leaf-bud cuttings: a tool for potato seed certification and breeding programs. Am. Potato J. 54:457464.

20. Lawrence, C. H. 1956. A method of isolating Actinomycetes from scabby potato tissue and soil with minimal contamination. Can. J. Bot. 34:44-47.

21. Lawrence, C. H., Clark, M. C., and King, R. R. 1990. Induction of common scab symptoms in aseptically cultured potato tubers by the vivotoxin, thaxtomin. Phytopathology 80:606-608.

22. Locci, R. 1994. Actinomycetes as plant pathogens. Eur. J. Plant Pathol. 100:179-200.

23. Loria, R., Kempter, A., and Jamieson, A. A. 1986. Characterization of Streptomyces spp. causing potato scab in the Northeast. Am. Potato J. 63:440.

24. Miller, I., and Berger, T. 1985. Bacterial identification by gas chromatography of whole cell fatty acids. Hewlett-Packard Application Note 228-41.

25. Mukula, J., and Rantanen, O. 1987. Climatic risks to the yield and quality of field crops in Finland. I. Basic facts about Finnish field crop production. Ann. Agric. Fenn. 26:1-18.

26. Ndwora, T. C. R., Kinkel, L. L., Jones, R. K., and Anderson, N. A. 1996. Fatty acid analysis of pathogenic and suppressive strains of Streptomyces species isolated in Minnesota. Phytopathology 86:138-143.

27. Oravuo, M. 1994. Applicability of "a pot method" for testing susceptibility to common scab (Streptomyces scabies) and for selection of breeding materials. M.S. thesis. University of Helsinki, Finland (In Finnish).

28. Paradis, E., Goyer, C., Hodge, N. C., Hogue, R., Stall, R. E., and Beaulieu, C. 1994. Fatty acid and protein profiles of Streptomyces scabies strains isolated in eastern Canada. Int. J. Syst. Bacteriol. 44:561-564.

29. Russell, N. J. 1989. Functions of lipids: Structural roles and membrane functions. Pages 279-365 in: Microbial Lipids. C. Ratledge and S. G. Wilkinson, eds. Academic Press, San Diego, CA.

30. Sasser, M. 1990. Identification of bacteria by gas chromatography of cellular fatty acids. Tech. Note 101. MIDI, Newark, DE

31. Scholte, K., and Labruyère, R. E. 1985. Netted scab: a new name for an old disease in Europe. Potato Res. 28:443-448.

32. Shirling, E. B., and Gottlieb, D. 1966. Methods for characterization of Streptomyces species. Int. J. Syst. Bacteriol. 16:313-340.

33. Suutari, M., and Laakso, S. 1993. Effect of growth temperature on the fatty acid composition of Mycobacterium phlei. Arch. Microbiol. 159:119-123.

34. Suzuki, K., Goodfellow, M., and O'Donnell, A. G. 1993. Cell envelopes and classification. Pages 195-250 in: Handbook of New Bacterial Systematics. M. Goodfellow and A. G O’Donnell, eds. Academic Press, San Diego, CA.

35. Takeuchi, T., Sawada, H., Tanaka, F., and Matsuda, I. 1996. Phylogenetic analysis of Streptomyces spp. causing potato scab based on 16S rRNA sequences. Int. J. Syst. Bacteriol. 46:476-479.

36. Tuomola, E., Rita, H., Kuisma, P., Somersalo, S., Pehu, E., Jokinen, K., and Valkonen, J. P. T. 1996. Occurrence of common scab in potato tubers after foliar treatment with glycinebetaine under glasshouse conditions. Agric Food Sci. Finl. 5:601-608. 